\title{
Philosophiques
}

\section{Descartes : le quatrième centenaire}

Volume 23, numéro 2, automne 1996

URI : https://id.erudit.org/iderudit/027403ar

DOI : https://doi.org/10.7202/027403ar

Aller au sommaire du numéro

Éditeur(s)

Société de philosophie du Québec

ISSN

0316-2923 (imprimé)

1492-1391 (numérique)

Découvrir la revue

Citer ce document

(1996). Descartes : le quatrième centenaire. Philosophiques, 23(2), 371-371.

https://doi.org/10.7202/027403ar

Ce document est protégé par la loi sur le droit d'auteur. L'utilisation des services d'Érudit (y compris la reproduction) est assujettie à sa politique d'utilisation que vous pouvez consulter en ligne.

https://apropos.erudit.org/fr/usagers/politique-dutilisation/
Cet article est diffusé et préservé par Érudit.

Érudit est un consortium interuniversitaire sans but lucratif composé de l’Université de Montréal, l'Université Laval et l'Université du Québec à Montréal. Il a pour mission la promotion et la valorisation de la recherche. https://www.erudit.org/fr/ 


\section{TABLE RONDE}

\section{DESCARIES : LE QUATRIÈME CENIENAIRE \\ Sous b direction de François Duchesneau}

Philosophiques est heureuse de s'associer aux célébrations qui ont marqué un peu partout dans le monde le quatrième centenaire de la naissance de Descartes. La revue publie ici quelques-unes des communications prononcées au colloque Descartes organisé en mai dernier par notre collègue, le professeur François Duchesneau, à l'occasion du colloque annuel de la SPQ à l'ACFAS 1996 qui se déroulait à l'université McGill.

N.D.L.R. 